\title{
Flipped-Small Private Tuition Online Course in Learning English for Rural Students
}

\author{
Siti Hajar Halili ${ }^{*}$, Hamidah Sulaiman² \\ ${ }^{1,2}$ University of Malaya, Malaysia \\ *Corresponding author: ajai912@gmail.com
}

\begin{abstract}
There is still a lack of studies to implement a Small Private Online Course for learning communities. This study aimed to identify the teaching and learning (T\&L) process carried out when using an English Flipped-Small Private Tuition Online Course (EESPtoc) based on Gagne's theory. Using purposive sampling, respondents were selected among rural primary school students. The respondents were introduced to the EESPtoc, which is a free tuition online platform for 4 sessions. A questionnaire and interview were used to collect data. SPSS software was used for data analysis in the form of descriptive statistics. Findings show that students have positive responses toward the use of EESPtoc and the interview had also supported the finding of the survey. To enhance this study, further research is recommended to look into the long-term effects of exploring retention of knowledge and skills from the use of the EESPtoc in the T\&L process.
\end{abstract}

Keywords: Primary students, rural areas, Gagne theory, English, flipped approach.

\section{Introduction}

Education plays an important role in improving a country's economic growth (Doris, Abdul, Norlida, Mohd, Redzuan and Siti, 2012). Mohamad, Asmawati, Abdullah, and Samsilah (2013) also state that education helps to overcome problems of moral decadence in the society, specifically among young children who will be a catalyst for the country. The development of technology in the Malaysian education system has grown. However, there is still a lack of studies focusing on the use of information communication and technology (ICT) in teaching and learning (T\&L) processes among communities in rural areas. Although the communities have begun to receive ICT technology development, challenges in the development of ICT in this area are still difficult to solve (Ministry of Education, 2016). Masayu (2016) reported that communities in the rural areas discouraged using ICT technologies due to various problems such as lack of interest and expertise in using ICT, lack of appropriate 
infrastructure and so forth.

The existing conventional teaching methods need to be transformed to ensure that the education system can move along with the advancements in technology. This is in line with the requirements of the Malaysian Ministry of Education to encourage educators and students to fully utilize the use of technology in the T\&L process. Recognizing the importance of education to rural students, the Malaysian Ministry of Rural and Regional Development (KKLW) takes the initiative to implement the 'society tuition class' program for rural students. This is because not everyone can afford private tuition and most of the less privileged families often struggle to provide their children with needed help in their academic studies.

The program introduced by KKLW started in 2013 and it is a free tuition program for rural students. The program was part of government efforts in helping children from low-income families, especially in rural areas to receive free tuition for the Primary School Achievement Test (UPSR). UPSR is a national examination taken at the end of the sixth year at the primary school level. For this program, KKLW has assigned teachers from the MARA Junior Science College (MRSM) to provide tuition for rural students. These teachers are being paid RM50 to RM100 per hour to get involved in this program. The tuition program uses existing classrooms in schools and applies the traditional learning approach (Malaysian Ministry of Rural and Regional Development, 2013).

To support the country's ICT master plan and in line with the country's drive to fulfill Vision 2020, the education system has to be transformed. Vision 2020 is a mission created by the Malaysian government to achieve a self-sufficient industrialized nation by the year 2020. The move is expected to bridge the digital divide between all communities of using technology as well as to provide an opportunity for all students to explore, use and develop various skills in using ICT (Masayu, 2016). As Massive Open Online Courses (MOOCs) are becoming more popular, Malaysia is taking a giant leap when the Minister of Education declared Malaysia as the first country in the world to implement MOOCs for all public universities (Ministry of Education, 2016; Fadzil, Latif and Azman, 2015). MOOC only began in Malaysia in March 2013 (Al-Atabi, \& DeBoer, 2014). There are many types of MOOC such as Non-connectivist Online Course (xMOOC), Connectivity MOOC (cMOOC), Distributed Online Collaborative Course (DOCC), Big Open Online Course (BOCC), Synchronous Massive Online Course (SMOC), Small Private Online Course (SPOC), Corporate MOOCs and Foreign Language Open Online Course (FLOOC) (Azhar, Mohd \& Mohd, 2016; Chauhan, 2014). 
The term "open" means there is no payment required to participate in MOOCs, and the openness element of MOOCs provides an opportunity for everyone to become a part of learning communities.

MOOC caters to the massive number of participants, whereas Small Private Online Course (SPOC) provides learning opportunities for a small group of participants. SPOC is one of the methods that have taken place and attention in the educational field. It is one of the elements of MOOC that applies the flipped classroom (FC) approach (Coughlan, 2013). Many studies have been done on MOOCs. However, there is still a lack of studies on the implementation of SPOC, specifically for learning community (Alario, Estévez, Pérez, Delgado \& Fernández, 2017: Azhar et. al. 2016; Peter, Laurel \& Alan, 2016; Bulfin, Pangrazio and Selwyn, 2014; Fox, 2014; Chauhan, 2014). In Malaysia, previous research indicated very few studies have investigated the FC approach and most of the FC studies focus on higher education institutions (Jamaludin \& Osman, 2014; Johary, 2015; Osman, Jamaludin \& Mokhtar, 2014; Rozhan, 2015). Not much research that focuses on the use of FC for the learning community had been reported.

In Malaysia, English as a second language is compulsory to be taught in school beginning from Primary 1 to Form 5 . The three main examinations in the school years are UPSR, Form 3 Assessment and Malaysian Certificate of Education, which feature English as a compulsory subject (Ministry of Education, 2016). However, English is not the home language of most Malaysians. Malaysian school students have different levels of knowledge and proficiency in the English Language. They often face difficulties in learning English and it is considered to be challenging for them (Ambigapathy, Liew, Tan, Lee, Toh \& Muniandy, 2014). The Malaysian Performance Management and Delivery Unit also reported that English is the students' weakest core subject in national assessments. The statistic showed that $25 \%$ of students fail in English examination (New Straits Times, 2015). Although the current tuition program has been introduced by KKLW, there is a need to enhance the program with minimal cost and time-saving using a technology-based approach.

In this pilot project, there is no amount will be paid to the teacher involved in this study. As compared to the current free tuition program by KKLW, the flipped online course is free and no charges will be imposed for using this course. This EESPtoc is designed to provide free academic assistance for rural primary school students to improve their English using technology-based learning. This project attempted to trial T\&L processes that would be more engaging and able to meet the target group of students' needs. It is also a pioneer study that aims to generate a deeper understanding of using technology to disseminate knowledge and best practices to the rural communities. This is because all communities need to increase their 
awareness and understanding in using ICT to improve the standard of the living and economic status of a society.

In Malaysia, research by Ambigapathy, Liew, Tan, Muniandy, Lee and Toh (2014) shows students who come from different backgrounds in which English is not the medium of instruction have difficulty in learning English. Not all students master in learning English and tend to have difficulty in learning the English language (Asgari \& Mustapha 2011). As a consequence, many Malaysian students are still struggling to understand and learn the English language (Selvaraj, 2010).

Teaching English in a traditional classroom tends to make the activity of teaching and learning ineffective (Wang \& Heffernan 2009). According to Sari (2019), using technology in learning English can therefore, encourage learners to learn. To facilitate the learning of English Language, Aljehani (2015) suggested the use of technology is more effective compared to traditional methods. Abbas (2012) stated that there is a significant role of technology in motivating EFL learners' interest in English language learning. Muslem and Abbas (2017) have also stated that the use of technology may be adapted to assist in learning the English language since it can produce the students with plentiful learning resources and instills more interest in learning. Flipped learning does not ignore traditional learning which has benefits in a physical face to face interaction in the class hours. In learning English, the concept of a flipped approach has integrated the traditional learning with technology-based learning environment (Fan, 2018). It allows learners to have access to educational content and have one way or two-way communications with other learners and instructors in and outside of class hours.

Recent research in instructional technology is focusing on artificial intelligence technologies, expands existing communication and information networks, focuses on curriculum revision and accountability, restructure classrooms, and explores the implications of new learning theories and teaching methods (Nelson, 2000). Gagne's significant contributions to the knowledge and understanding of instructional technology were well documented. The impact of Gagné's work on new technologies in education influences on the developments in instructional technology. Nelson also added that Gagne's work on the latest instructional technologies not only consists of tools and processes but also the knowledge sources and activities to design, develop, utilize, manage and evaluate instruction. It is essential to base in instructional technology principles such as those presented by the Gagne theory to meet the needs of new generations of learners. Thus, the main objective of this research is to identify the T\&L processes carried out when using an English Flipped-Small Private Tuition Online Course (EESPtoc) based on Gagne's theory. The research question of this study is 'What is the rural students' perceptions in T\&L processes carried out when 
using an English Flipped-Small Private Tuition Online Course (EESPtoc) based on Gagne's theory?'.

\section{Methodology}

This study was conducted using a mixed methods design. According to Klassen, Creswell, Clark, Smith and Meissner (2012), a mixed-methods research design is a procedure for collecting, analyzing, and mixing both quantitative and qualitative methods in a single study or a series of studies to understand a research problem. To emphasize, qualitative data would help develop and elaborate quantitative data (Creswell, 2013). Therefore, a questionnaire survey and interview were used to collect the data. The course was the English language, a compulsory course for all primary students in secondary school and the weakest core subject in Malaysian national assessments.

\section{Participants}

This research is conducted among primary school students living in a rural areas in Malaysia. There were a few factors that need to be considered to integrate the study for rural students, such as the availability of technological access and internet connections. Purposive sampling technique was used in sample selection for this research. The students were selected based on their parents' willingness to guide their children to participate in the study and support the technological access to utilize the flipped activities at home. Forty respondents were selected among standard primary school students. They were invited to attend in-class activities at community hall every weekend for 4 sessions.

\section{Data Collection Procedures}

Gagne's nine events of instruction theory were selected to apply in this research because Gagne's theory helps educators understand the efficiency and effectiveness of the T\&L processes. It also gives educators a much clearer direction to teach students, according to the appropriate teaching method and child's cognitive level. Each step in this theory can serve as a checklist before the delivery of a lesson (Centre for Instructional Technology \& Training, 2017). Gagne's theory emphasizes the information processing model which allows learning to take place and provides a practical roadmap to integrate the use of technology at various stages of instruction. 
Events 1 to 5 are the instruction for students to watch videos or read any learning materials at home and before they enter the classroom. Events 6 to 9 on the other hand, are activities that take place in the classroom after students have watched the video or read any learning materials at home or anywhere outside the classroom setting (Refer to figure 1).

Students are generally misunderstood about English lessons (Nguyen \& Terry, 2017). Hoover, Sarris, and Hill (2015) highlight the need to make appropriate pedagogical modifications in learning the English language. Learning referred to the process of students' learning with a new instruction or approach. In other words, the term "learning" would show whether students had a positive perception and experiences of learning English in the flipped environment. In this study, students would learn English via online platform. The theoretical framework for this study is based on Gagne's theory which the theory focuses on the knowledge and understanding of using technology in the teaching and learning process. Banas and Velez-Solic (2013) assured that intended learning can be attained if these nine steps in Gagne's theory are followed. Gagne (1987) addresses the role of instructional technology in learning thus the use of technology can provide meaningful experiences for students to learn the English language. We chose to use Gagne's theory in this study because it works on principles of independent thinking which in turn helps students to acquire skills and knowledge effectively. This is because this theory can extend the process and content of learning so that learning is facilitated and easily understood, enjoyable and engaging for students in the T\&L processes (Andrew, 2017).

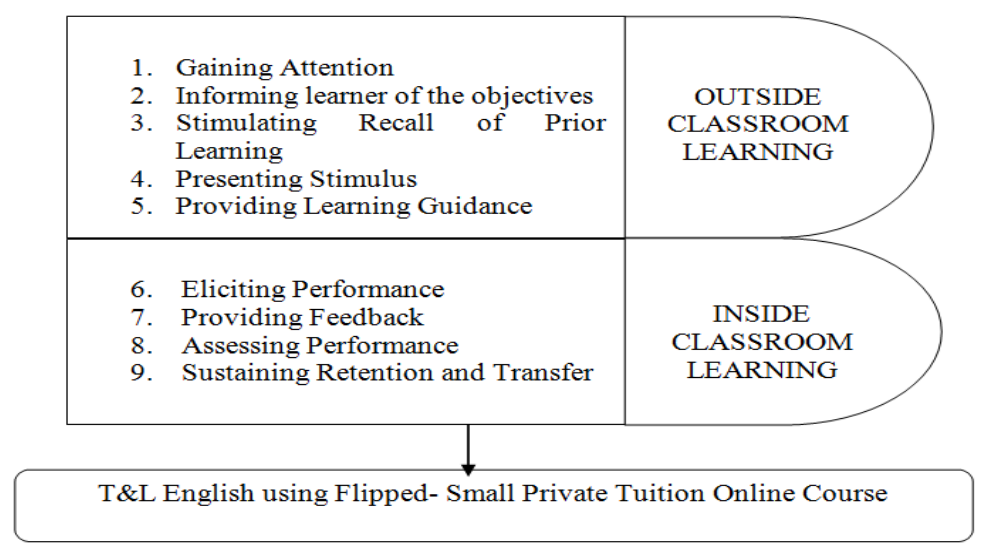

Figure 1. The combination between steps in implementing EESPtoc and Gagne's theory

According to Ozan and Adile (2015), the use of videos is not the only requirement to implement the FC approach. Thus, in this study, students were given learning 
materials such as exercises, notes or links to Web sites (article, blog, videos, etc.). In this research, the learning materials were given to the students before class based on the standard six Malaysian syllabuses for English subject. At home, students could easily and flexibly learn the English contents according to their preferred time and place, they attended class. In class, the teacher zoomed into learning activities such as exercises, discussion, and quizzes. The researcher briefed the participants on using EESPtoc and requested them to review the learning materials at home for four sessions. For the duration of FC activities, there was no information on the guidelines of what should be the right methodology for the flipped approach and how the design of in-class activities complemented the flipped component. Thus, in this study, the activities in and outside the classroom are based on Sams and Bergman flipped model (2013). Sams and Bergman flipped model (2013) have integrated traditional learning with a technology-based learning environment and it allows learners to have access to educational content inside and outside of class. These steps were adopted and modified by Sams and Bergman (2013).

This study selected to utilize SPOC as compared to other types of MOOCs because this research only focused on a subject related to the English language and also consists of small numbers of participants. According to a website from MOOCLAB, University of California, SPOC can consist of less than a full course, for example, one subject/course or a subset of course material that uses online resources. Therefore, SPOC is suitable to be used in this study. There are many platforms available such as OpenLearning (OL), Khan Academy, Academic Earth, Udemy, Coursera, edX, and Udacity for educational purposes. The use of the OL platform is used as a platform in this study considering that this platform is free, access to the platform is free for a small number of groups and one of the online learning platforms focused on community and able to create a learning community (OpenLearning, 2016). The small class size will allow more interaction between instructor and students, assessment and greater active participation in EESPtoc. At the end of the course, all participants will be given a certificate by the researcher as a token of their participation in this study.

\section{Data Analysis Procedures}

Forty students participated in the survey questionnaire. A questionnaire was used in this study to identify the T\&L processes carried out when using EESPtoc in learning English. The questionnaire is adapted from previous research by Siti (2011). The questionnaire consists of 18 items based on the nine events of instruction as proposed by Gagne's theory. The study used of four-point Likert scale to obtain the level of 
usage of each element and also the neutral or unsure response by the respondent (Trochim, 2002). The validity and reliability of the questionnaire had been verified in the researcher's previous research (Siti, 2011). The result of Cronbach's alpha is 0.93, had internal consistency reliability which higher than 0.7 . Thus, the result indicated that the items used were adequate and reliable. All data and information collected were analyzed by the researcher using statistical analysis that provided percentage, mean, and standard deviation using the SPSS version 17.0 software.

This study also used the focus group interview to obtain a more in-depth survey of students' learning English using EESPtoc. This analysis was used to support the findings of a questionnaire survey. According to Patton (2002), there are around six to ten people usually involved in a small focus group interview and this interview aims to improve participants' confidence in explaining their ideas. In this study, six students participated in the focus group interview (three males and three female participants). They were named S1, S2, S3, S4, S5, and S6. They were chosen because of their willingness to participate in the interview after the end of four class sessions. In this study, the process of focus group discussion was also audio-recorded and transcribed. The researcher could produce the accuracy of students' responses and statements. Henceforth, all participants' quotes were transcribed verbatim and may contain many errors in grammar and punctuation because English is not the first or second language of the participants. They could understand the English language since they were introduced in the English subject starting from early childhood education. Again, some students also mixed their language with English and Malay language. The duration of the interview was one hour and thirty minutes. The researcher used the semi-structured interview because its casual style allows more flexibility and freedom in communication. According to Kajornboon (2004), semistructured interviews are a freestyling interview compared to a structured interview. The interview questions were modified from previous research done by Zamzami (2016) to ensure that the questions were understandable by young children. The questions were as follows: (1) How was your experience in using EESPtoc in learning English, (2) How did you feel in learning English using EESPtoc, and (3) Please state any other comment and suggestion you wish to state about the use of EESPtoc in learning English?.

All answers and feedback received from the interview session are categorized based on the interview questions. After identifying the contents into a theme, the researcher arranges the data and reports it descriptively according to the themes. 


\section{Results}

\section{Quantitative results}

The students' perception of the use of this EESPtoc in the T\&L was analyzed using their responses to the questionnaire and interview. Table 1 displays the results of the descriptive analysis of the students' responses to the questionnaire in the form of percentages, means, and standard deviations.

\section{Table 1}

Students' responses to the questionnaire items in the form of percentages, means and standard deviations

No Items $\quad \begin{gathered}\text { Means } \\ \text { Non })\end{gathered}$

\section{Gaining Attention}

1. EESPtoc helped me to focus on relevant topics in learning

2. I am more motivated to learn English using EESPtoc

3. Informing the learner of the objectives

The T\&L process using EESPtoc help to improve the

4. I am ready for the topics I have been informed about earlier

\section{Stimulating Recall of Prior Learning}

The T\&L process using EESPtoc helped me to recall the

6. I can gain more knowledge of previous concepts in learning

English using EESPtoc

Presenting the Stimulus

7. I can distinguish the important and relevant information from 
8. I pay more attention to learning English using EESPtoc as it

helps me to understand the lesson more effectively

Providing Learning Guidance

9. I am satisfied with the way English was taught using EESPtoc

10. I can remember the information received during the $T \& L$

process using EESPtoc

11. Eliciting performance

Using EESPtoc in T\&L process helped me to increase my

understanding of what I have learned in the lesson

12. I will compare the knowledge I have learned in learning

English using EESPtoc with other learning materials

13. Providing Feedback

Feedback from the teacher was given more clearly in the T\&L

process

14. I responded promptly to questions raised by a teacher

\section{Assessing performance}

I showed better performance in the $\mathrm{T} \& \mathrm{~L}$ process using

EESPtoc

16. I am confident to participate in the $\mathrm{T} \& \mathrm{~L}$ process using

EESPtoc

\section{Enhance Retention and Transfer}

17. What I learned in the T\&L session using EESPtoc helped me to learn with other learning materials

18. I can retain information and transfer new knowledge to different situations.

SD - Standard Deviations, T\&L - Teaching and Learning

There were 18 items in this survey analysis to identify the T\&L processes carried out when using EESPtoc based on Gagne's theory. Items 1 and 2 represented the gaining attention, items 3 and 4 - informing learners of the objectives, items 5 and 6 - the stimulating recall of prior learning, items 7 and 8 - presenting the stimulus, 
items 9 and 10-providing learning guidance, items 11 and 12 - eliciting performance, items 13 and 14 - providing feedback, items 15 and 16 - assessing performance and items $17 \& 18$ - enhance retention and transfer. Items 1 and 2 reported that overall students had a positive attitude toward this item. $86 \%$ students with a mean score ( $M$ $=2.88, S D=0.97$ ) were satisfied that EESPtoc help them to focus on relevant topics in learning English and $88 \%$ students with a mean score $(M=2.84, S D=0.96)$ were motivated to learn English using EESPtoc. Items 3 and 4 showed that $78 \%$ students with a mean score $(M=2.80, S D=0.94)$ positively declared that the T\&L process using EESPtoc help to improve the expected performance of their learning, and 79\% students positively with a mean score $(M=0.83, S D=0.95)$ responded that they were ready with the topics that have been informed. Item 5 showed $74 \%$ of students agreed that the T\&L process using EESPtoc helped them to recall the concepts they have learned before class with the mean score $(M=2.64, S D=0.93)$. Item 6 also showed that $73 \%$ of students with a mean score $(M=2.63, S D=0.91)$ agreed that they were able to gain more knowledge of previous concepts in learning English using EESPtoc. Further, for item 7, 71\% of students had a positive response to the statement that they were able to distinguish the important and relevant information from less important in the T\&L process with the mean score $(M=2.66, S D=0.92)$. Item 8 also showed $77 \%$ students with a mean score $(M=2.71, S D=0.93)$ responded positively to this statement. The finding showed that they paid more attention to using EESPtoc in theT\&L process as it helps them to understand the lesson more effectively. Items 9 and 10 showed $73 \%$ students with a mean score $(M=2.67, S D$ $=0.91)$ and $72 \%$ students with a mean score $(M=2.63, S D=0.90)$ responded positively to the statement. This means they were satisfied with the way English was taught and able to remember the information received during the T\&L process using EESPtoc.

Items 11 and 12 showed $78 \%$ students with a mean score $(M=2.77, S D=0.90)$ positively declared the T\&L process using EESPtoc help to increase their understanding on what they have learned in the lesson, and $75 \%$ students positively with a mean score $(M=0.75, S D=0.93)$ responded that they will compare the knowledge they have learned in learning English using EESPtoc with other learning materials. Item 13 showed $78 \%$ of students agreed the feedback from the teacher was given more clearly in the T\&L process with the mean score $(M=2.79, S D=0.94)$. Item 14 also showed $77 \%$ of students with a mean score $(M=2.76, S D=0.90)$ agreed they responded promptly to questions raised by the teacher. Further, $76 \%$ and $74 \%$ of students had a positive response to statement in item 15 and 16 that they showed better performance and were confident in the T\&L process using EESPtoc with the mean score $(M=2.73, S D=0.92)$ and $(M=2.69, S D=0.90)$. Item 17 also showed $82 \%$ of students noted positively in the statement. The mean score $(M=2.83, S D=$ 0.95 ) also indicated that almost all respondents had a positive view of this item. The 
last item (item 18) of students' learning stated: 'I can retain information and transfer the new knowledge to different situations', showed $80 \%$ of students noted positively to the statement with the mean score $(M=2.80, S D=0.92)$.

\section{Qualitative results}

The finding of the interview results also showed that students had positive responses toward the T\&L process using ESPtoc. We classified the raw data into specific themes. The themes are the overall discussions which are based on the interview findings. It has become easier for the researcher to put it into a theme for analysis. Three themes as illustrated in Figure 3 emerged during the interview process in terms of students' learning: (1) Active learning experiences, (2) Motivation in learning English, and (3) Recommendation to use ESPtoc in the future.

\section{Active learning experiences}

Respondents were asked to explain their experience in using ESPtoc in learning English. All of the students mentioned that the use of ESPtoc in learning English helped them to be active participants rather than in a traditional class.

Student (S1) stated, "I become an active learner. I like the way this subject was taught compared to a traditional class. I had more opportunities to communicate in English with peers and teachers." (S1)

Student (S2) emphasized, "I become an active learner not only in class but before I attend the class. The in-class activities were fun and I enjoyed the way English was taught in using this flipped online course. I have watched videos and read notes at home. I think the flipped online course is interesting and enjoyable". (S2)

Student (S3) added, "I always log in to the flipped platform before attending the class. I am ready for learning experiences in and outside the class, which the teacher had previously told. I wanted to be well-prepared to be part of the class discussion". (S3)

Student (S4) agreed, "I enjoyed the experience of learning something new. Using this flipped online course makes me become an active learner as compared to traditional approaches. I could improve my understanding of learning the English language." (S4)

Student (S5) and student (S6) noted that they enjoyed learning English using the flipped online course. They were able to participate in class activities and paid more attention to learn English using ESPtoc. 
From this theme, it can be concluded that learning English using ESPtoc helps students to participate more actively than in a traditional class.

\section{Motivation in learning English}

The students were requested to explain their opinion in learning English using ESPtoc. The majority of the students mentioned that they were motivated to learn English using ESPtoc as compared to traditional approaches. Students (S1, S2, and S3) stated that learning English using ESPtoc increased their motivation to obtain new knowledge. This statement was also supported by students (S4) which mentioned: "I feel motivated learning English. Using video lectures on the flipped online course had motivated me in learning English. I am excited to sit for UPSR because I am more confident in my English language".

Student (S5) agreed, "Using this flipped online course in learning English has motivated me to obtain a good result in UPSR. I hope I can perform well in my English subject." (S5)

Student (S6) also supported their statements, "The flipped online course has motivated me to better understand English subject. For me, I feel motivated by the inside and outside activities of this class. Although I do not know what the online course was at first, I enjoy using this approach now." (S6)

Based on the interview findings, the flipped online course had successfully constructed students' motivation in learning English. The interview data revealed that they were being motivated in learning English using ESPtoc.

\section{Recommendation to use EESPtoc in future}

Respondents were asked to express their comments and suggestions for the improvement of using ESPtoc in learning English. Students (S2 and S6) stated that they need more additional academic guidance in the T\&L process using ESPtoc. This is because they were not from a rich family as their parents were not able to pay extra money for private tutoring. They hope there will be more initiatives to introduce the ESPtoc not only in English subject but also in other core subjects.

Student (S1) suggested, "The course is free so I hope it can be accessed by anyone, anywhere as long as they have an internet connection. This will enable learners from other states to participate in this course. By using this flipped online course, my study time after school is valuable. I learn English not only at school but also after school hours." (S1) 
Student (S5) also agreed, "Yes, I do hope other schools nationwide will use this flipped online course in the T\&L process. Previously I have limited exposure to learning English. However, using this flipped online course activities attract my interest to learn in and outside of class." (S5)

Student (S3) added, "T\&L process using technology provides more interest in learning English. I hope Malaysian schools will move away from using traditional approaches in the classroom. I hope my school teachers will use the flipped approach to learn English or any other subjects" (S3)

Student (S4) also added, "If there is a flipped online course for other subjects. I will voluntarily participate and register again. I can learn more in this flipped online course." (S4)

Based on their statements, the researcher concluded that all students' statements were valuable for improving ESPtoc. This theme also showed that almost all participants in this study hoped that there will be more initiatives to introduce the ESPtoc not only in English subject but also in other core subjects.

\section{Discussion}

On the whole, it was found that the percentages recorded in Table 1 show more than $60 \%$ of students agreed with the questionnaire items presented. The role of information technology in education must be seen as something that accelerates the learning process more effective. In this study, the ESPtoc which is based on Gagne's theory facilitated the T\&L processes throughout their session. This means that the use of the FC approach has helped the teacher to deliver the content of the lesson and expedite the T\&L. This study resonates with a study done by Yee (2018) which found that Gagne's theory in the teaching of Goldmann Applanation Tonometry has helped to accommodate the learning process. Although this flipped online course was considered as a new learning culture for the students, they agreed that flipped online course had satisfied their understanding of learning English.

From the interview findings, the majority of respondents' statements recognized that using ESPtoc in learning English has helped them to be more active participants rather than in a traditional class. This theme of active learning experiences showed that almost all participants in this study acknowledged that applying flipped online course in learning English was more effective as compared to the traditional classroom. The finding of this study was supported by research done by Ayçiçek and Yanpar (2018) and Zappe, Leicht, Messner, Litzinger and Lee (2009) that mentioned 
an active learning environment tends to make the students actively involved in a discussion and problem-solving. Zhiru, Kui and Lynley (2018), Chung, Chi and Khe (2018) and Overmyer (2012) also believed that in the FC, students are more confident and active in classroom activities because they have prepared to learn material outside of the class. In this study, using a flipped online course has helped the rural students to construct their motivation in learning English. These findings are congruent with the statement of Jian (2018) and Enfield (2013) that FC supports students' motivation in obtaining new content and learning environment in a group. Findings by Chung, Chi and Khe (2018) also revealed that language learners were benefits from the FC approach. Although the research done by Darus and Ching (2009) stated that Malaysian school students present a low motivation to learn English lessons, this study confirmed that they were motivated by learning English using ESPtoc. The respondents also suggested the ESPtoc platform can share any learning materials to any Malaysian schools nationwide. This study is also relevant to with Given and Amanda (2018) which found that in the FC approach, students were more engaged and enjoyed learning English. Thus, it is envisioned that this pilot project could be shared with other participants nationwide and everyone has access to the free online course. This is because learners are not required to make an extensive financial commitment before embarking on a course. Anyone can join the course, as long as they have an internet link, is available to anyone without eligibility for admission, and provide a fully online learning experience for free.

It can be concluded that the majority of respondents' statements agreed that using ESPtoc in learning English was meaningful. Respondents were satisfied with the way English was taught inside and outside the classroom. It was consistently supported by the previous survey result for item 2: I was more motivated to learn English using ESPtoc, item 4: I was ready with the topics that I have been informed earlier, item 8: I paid more attention in learning English using ESPtoc as it helps me to understand the lesson more effectively, item 9: I was satisfied with the way English was taught using ESPtoc, item 11: Using ESPtoc in T\&L process helped me to increase my understanding on what I have learned in the lesson and item 17: What I learned in the T\&L process using ESPtoc helped me to learn with other learning materials. The findings showed a positive response in both the questionnaire and interview data. The interview findings had supported the finding of a questionnaire survey. It could be concluded that most students had constructed their positive perceptions of learning English using ESPtoc.

\section{Conclusion}


The integration of ICT in the Malaysian classroom needs serious consideration to increase the competency of the country's education system (Simin \& Sani, 2015). The needs of educational transformation in terms of value and morality are very important, especially among students who will be the catalyst for the country's future development. This study is important because it will determine the future development of using technology among communities in rural areas. Kathleen and Margaret (1999) stated that LC is a group of people who share the same interest in a topic or area. They will enroll in a course and learn together, which can be used for the benefit of the community. Yarnit (2000) reported that LC is the way to promote social cohesion and generate economic development. Sue et. al., (2003) and Camacho (2006) believed that learning communities can share a new knowledge among groups of people and the use of ICT will build on the development opportunities between each community in a country. ICT awareness and skills should be introduced to communities in rural areas since the development of ICT technology is capable to change the growth of the country's economy (Acacia, 2000). Thus, authorities have to plan and take proper actions to strengthen the use of ICT for these communities.

This study has helped rural primary school students seeking academic support in learning English and motivating them to increase their future academic performance. The ESPtoc also helped to sensitize on issues related to the rural students since the Malaysian government strives to enhance its ICT development strategy in rural areas. This study is hoped to lead to greater awareness of the potential of open online education for the LC. The findings could help the instructional designer to create a better way of learning for the learning communities in using flipped online learning. This can help to attract students' participation in learning activities. The findings of this research could help make recommendations and provide a guideline to the Malaysian education technology division or policymakers in other countries to highlight this SPOC specifically for learning communities using any other online platform. Policymakers and practitioners should seriously examine the research on SPOCs to transform the traditional learning approach to the technology-based learning environment which provides a means of offering a more flexible learning environment. The current tuition program which related to the academic tuition guidance has paid RM50 to RM100 per hour to teachers involved in this program. In this pilot project, there is no amount be to be paid to teachers because the flipped online course is free and no charges will be imposed for using this course.

The small sample size became the limitation of this research because it involved forty students in learning English for four sessions and also students in this study referred to rural primary students. Thus, future research should involve a big samples in terms of size and increase the length of the study. More studies that included 
different ages of participants, different groups, ethnicities, and places should be chosen to obtain deep more information about different cases of applying flipped classrooms. Almost all participants in this study hoped that there will be more initiatives to introduce the ESPtoc not only in English subject but also in other core subjects. It is suggested that future studies will be in other core subjects such as Malay language, Mathematics, and Science. To enhance this study, further research is recommended to look into the long-term effects in exploring retention of knowledge and skills from the use of the ESPtoc in theT\&L process.

\section{Acknowledgment}

$\mathrm{I}^{10}$ would like to acknowledge the financial support provided by the University of Malaya under the Equitable Society Research Cluster (ESRC) research grant RP020A-14SBS.

\section{References}

Abbas, P. (2012). The significant role of multimedia in motivating EFL learners' interest in English language learning. International Journal of Modern Education and Computer Science, 4(4), 57-66.

Acacia, C.P. (2000) Information and communication technologies (ICTs) for improved service delivery in the new South Africa. Available from: http://www.citizens.csir.co.za/ <http: www.citizens.csir.co.za/="">326-329. [Accessed 15th January 2019].

Al-Atabi, M., \& DeBoer, J. (2014) Teaching entrepreneurship using massive open online course (MOOC). Technovation, 34 (4), 261-264.

Alario, H., Estévez, A., Pérez, S., Delgado, K., \& Fernández, P. (2017) Understanding Learners' Motivation and Learning Strategies in MOOCs. International Review of Research in Open and Distributed Learning, 18 (3), 119-137.

Aljehani, W.M. (2015). Using PREZI Presentation Software to Enhance Vocabulary Learning of EFL Secondary School Students. Educational Research International, 4(4), 67-81.

Ambigapathy P., Liew, C.C.L., Tan, D.A.L., Jayagowri, M., Lee, B.C., \& Toh, C.H. (2014). Language teaching and learning: New dimensions and interventions (Eds.). Newcastle upon Tyne, UK: Cambridge Scholars Publishing.

Ambigapathy, P., Liew, C.L.C, Tan, D.A.L., Lee, B.C., Toh, C.H., \& Muniandy, J. (2013) New Literacies: Reconstructing Education and Language. United Kingdom: Cambridge Scholars Publishing.

\footnotetext{
${ }^{10}$ Dr Siti Hajar Halili, Senior Lecturer at the University of Malaya.
} 
Andrew, L. (2017) Gagne's Theory of Learning - Part II. Available from: http://www.brainychild.com/articles/Gagne-theory-of-learning-2.shtml [Accessed 15th January 2019].

Asgari, A. \& Mustapha, A. B. (2011) The Type of Vocabulary Learning Strategies Used by ESL Students in University Putra Malaysia. English Language Teaching 4(2), 84-90.

Ayçiçek, B., \& Yanpar, Y. T. (2018) The effect of flipped classroom model on students' classroom engagement in teaching English. International Journal of Instruction, 11 (2), 385-398.

Azhar, S.R., Mohd, F.D., \& Mohd, N.H. (2016) MOOCs in Engineering Education- A Literature. Review. Available from: https://www.academia.edu/28507541/MOOCs_in_Engineering_Education_A_Litera ture Review [Accessed 17th January 2019].

Banas, Jennifer \& Velez-Solic, A. (2014). Designing effective online instructor training and professional development, 732-756. DOI: 10.4018/978-1-4666-5780-9.ch041

Bulfin, S., Pangrazio, L., \&Selwyn, N. (2014) Making 'MOOCs': The construction of a new digital higher education within news media discourse. The International Review of Research in Open and Distributed Learning, 15 (5), 290 - 305.

Camacho, K. (2006) Digital Divide. Available from: http://vecam.org/article549.html [Accessed 19th January 2019].

Center for Instructional Technology \& Training. (2017) Gagne's 9 Events of Instruction. Available from: http://citt.ufl.edu/tools/gagnes-9-events-of-instruction/ [Accessed 15th January 2019].

Chauhan. A. (2014) Massive Open Online Courses (MOOCS): Emerging Trends in Assessment and Accreditation, Digital Education Review, 25, 7-17.

Chung, K.L., Chi,W, L., \& Khe, F.H. (2018) Applying "First Principles of Instruction" as a design theory of the flipped classroom: Findings from a collective study of four secondary school subjects. Computers \& Education, 118, 150-165.

Coughlan, S., (2013) Harvard plans to boldly go with 'Spocs'. Available from: http://etcjournal.com/2013/09/26/spocs-are-mooc-game-changers/ [Accessed 15th January 2019].

Creswell, J. W. (2013) Research design: Qualitative, quantitative, and mixed methods approaches. Thousand Oaks, CA: Sage.

Darus, S. \& Ching, K. (2009) Common errors in written English essays of Form One Chinese Students: A case study, European Journal of Social Sciences, 10 (2): 242- 245.

Doris, P. S, Abdul, H, J, Norlida, H, Mohh, S, Redzuan, O, I, \& Siti, H. (2012) Human Capital Transformation through Improved Education: A Case Study in Cameron Aboriginal Community Highlands, Pahang Human Capital Transformation through Education: Case Study of the Aboriginal Community in Cameron Highlands, Pahang. Available from: http: //www.ukm.my/fep/perkem/pdf/perkemVII/PKEM2012_4D3.pdf [Accessed 19th January 2019].

Enfield, J. (2013) Looking at the impact of the flipped classroom model of instruction on undergraduate multimedia students at CSUN. TechTrends, 57 (6), 14-27.

Fadzil, M., Latif, L. A., \&Azzman, T. A. M. T. M. (2015) MOOCs in Malaysia: A preliminary case study. MOOCs in Malaysia: a preliminary case study. Available 
from: $\quad$ http://library.oum.edu.my/repository/1022/1/library-document-1022.pdf [Accessed 15th January 2019].

Fan, X. (2018). Research on oral English flipped classroom project-based teaching model based on cooperative learning in China. Journal of Educational Sciences: Theory \& Practice, 18(5), 1988-1998.

Fox, A. (2014) From MOOCs to SPOCs: Curricular technology transfer for the $21^{\text {st }}$ Century, Ubiquity, 1-13.

Gagne, R.M. (1987). Instructional Technology Foundations. Hillsdale, NJ: Lawrence Erlbaum Assoc.

Gagne, R. M. (1985) The conditions of learning and theory of instruction. $4^{\text {th }}$ ed. New York, New York: Holt, Rinehart \& Winston.

Given, L., \& Amanda,W. (2018) Flipped learning in the English as a foreign language classroom: Outcomes and Perceptions. TESOL quarterly, 52 (1), 62-84.

Hoover, J. J., Sarris, J. S., \& Hill, R. (2015). Increasing usage of ESL instructional practices in a rural county elementary school. Retrieved from: https://files.eric.ed.gov/fulltext/EJ1225302.pdf [Accessed 17th Mac 2020].

Huseh, H.C., Chih, Y.W., \& Ching, H.C. (2018) Which students benefit most from a flipped classroom approach to language learning. British Journal of Educational Technology, 49 (1), 56-68.

Jamaludin, R., \& Osman, S. Z. (2014) The use of a Flipped Classroom to enhance engagement and promote active learning. Journal of Education and Practice, 5 (2), 124-131.

Jian, Q. (2018) Effects of Digital Flipped Classroom Teaching Method Integrated Cooperative Learning Model on Learning Motivation and Outcome. Eurasia Journal of Mathematics, Science and Technology Education. 14 (6), 2213-2220.

Johary, J. (2015) Flipped Classroom at the Defence University: A pilot study. Available from: http://eli.elc.edu.sa/2015/sites/default/files/(51)\%20Jowati\%20Juhary.pdf [Accessed 15th January 2019].

Kathleen, P. F., \& Margaret, R. (1999) Professional development through learning communities. Available from: https://www.edutopia.org/professional-developmentthrough-learning-communities [Accessed 15th January 2019].

Kajornboon, A. B. (2004) Creating Useful Knowledge: A Case Study of Policy Development in E-learning at Chulalongkorn University Language Institute. (Dissertation). University of Melbourne: Australia.

Klassen, A. C., Creswell, J., Clark, V. L. P., Smith, K. C., \& Meissner, H. I. (2012) Best practices in mixed methods for quality of life research. Quality of Life Research, 21 (3), 377-380.

Masayu, S. R. (2016) Instructions for use of ICT and public perceptions of ICT use among rural women entrepreneur. Geografia-Malaysian Journal of Society and Space, 12 (3), 50-60.

Malaysian Ministry of Rural and Regional Development. (2013) Tuisyen Rakyat@KKLW Programme.

Available from: http://www.rurallink.gov.my/en/tuisyen-rakyatkklw-programme/ [Accessed 15th January 2019]. 
Ministry of Education, (2016) Preliminary Report: Malaysia Education Blueprint 2013-2025. Available from: http://www.moe.gov.my/userfiles/file/PPP/Preliminary-BlueprintEng.pdf [Accessed 15th January 2019].

Mohamad, K. O., Asmawati, S., Abdullah, M.R., \& Samsilah,R. (2013) Social factors relationships withthe appreciation of pure student values. Journal of Applied Research in Education, 17, 56-76.

Muslem, A., \& Abbas, M. (2017). The Effectiveness of Immersive Multimedia Learning with Peer Support on English Speaking and Reading Aloud. International Journal of Instruction, 10(1), 203-218.

Nelson, W. (2000) Gagne' and the new technologies of instruction. Available from: https://www.researchgate.net/profile/Wayne_Nelson/publication/263963729_Gagne' _and_the_new_technologies_of_instruction/links/54fdd50f0cf270426d12ce80.pdf [Accessed 15th January 2019].

New Straits Times (2015) All-round concerted efforts needed. Available from: https://www.nst.com.my/news/2017/03/117441/all-round-concerted-efforts-needed [Accessed 15th January 2019].

Nguyen, H., \& Terry, D. R. (2017). English Learning Strategies among EFL Learners: A Narrative Approach. IAFOR Journal of Language Learning, 3(1), 4-19.

OpenLearning. (2016) What is OpenLearning. Available from: https://www.openlearning.com/About [Accessed 15th January 2019].

Osman, S. Z., Jamaludin, R., \& Mokhtar, N.E. (2014) Flipped classroom and traditional classroom: lecturer and student perceptions between two learning cultures, a case study at Malaysian polytechnic. International Education Research, 2 (4), 16-25.

Overmyer, J. (2012) Flipped classrooms 101. Principal, 46-47.

Ozan, F., \& Adile, K. (2015) Flipped learning: Misunderstandings and the truth. Journal of Educational Sciences Research, 5 (1), 215-229.

Patton, M. Q. (2002) Qualitative research and evaluation methods. 3rd ed. Thousand Oaks, CA: Sage Publications.

Peter, R. D., Laurel H, T., \& Alan, W. (2016) A Snapshot of MOOCs in Hospitality and Tourism, Journal of Hospitality \& Tourism Education. 28(2), 107-112.

Pinfan, Z., \& Kirk, S.A. (2010) An application of Robert Gagne's nine events of instruction to the teaching of website localization. Journal Technical Writing and Communication, 40 (3), 337-362.

Rozhan, M. I. (2015) The mobile learning flipped classroom. Available from: http://www.wseas.us/e-library/conferences/2015/Malaysia/EDU/EDU-10.pdf [Accessed 19th January 2019].

Sams, A., \& Bergmann, J. (2013) Flip your students' learning. Educational Leadership, $70(6), 16-20$.

Shakenova, L. (2017) The Theoretical Framework of Teacher Collaboration. Khazar Journal of Humanities and Social Sciences, 20 (2), 34-48.

Selvaraj,B (2010) English Language Teaching (ELT) Curriculum Reforms in Malaysia. Voice of Academia, 5(1), 51-60. 
Simin, G., \& Sani, I. M. (2015) Effectiveness of ICT Integration in Malaysian Schools: A quantitative analysis. International Research Journal for Quality in Education, 2 (8), $1-12$.

Siti, H. H. (2011) The Effectiveness of Learning Process Using Video Conferencing Technology. Jurnal Pendidikan Malaysia, 36 (1), 55-65.

Sue, K., Margaret, B., \& Tammy, J. (2003) Defining learning communities. Available from: http://www.aare.edu.au/data/publications/2003/jon03441.pdf [Accessed 15th January 2019].

Trochim, W. M. (2002) Likert scaling. Available from: http://www://rochim.human.cornell.edu/kb/scalik.htm [Accessed 15th January 2019].

Yarnit, M. (2000) Towns, cities and regions in the learning age: A survey of learning communities. $\quad$ Retrieved from: http://www.ala.asn.au/learningcities/LGALearningLayout.pdf [Accessed 15th January 2019].

Wang, S., \& Heffernan, N. (2009). Ethical issues in computer-assisted language learning: Perceptions of teachers and learners. British Journal of Educational Technology, 41(5), 796-813.

Yee, L.W. (2018) Utilizing the principles of Gagne's nine events of instruction in the teaching of Goldmann Applanation Tonometry. Advances in Medical education and Practice, 9, 45-51.

Zamzami, Z. (2016) English language learners' perceptions on the use of flipped learning approach at a university. (Dissertation). University of Malaya: Malaysia.

Zappe, S., Leicht, R., Messner, J., Litzinger, T., \& Lee, H. (2009) "Flipping" the classroom to explore active learning in a large undergraduate course. American Society for Engineering Education. Available from: http://soa.asee.org/paper/conference/paperview.cfm?id=10046 [Accessed 19th January 2019].

Zhiru, S., Kui, X., \& Lynle, H.A. (2018) The role of self-regulated learning in students' success in flipped undergraduate Math courses. The Internet and Higher Education, $36,41-53$. 